\title{
Octreotide, a Somatostatin Analogue, Mediates Its Antiproliferative Action in Pituitary Tumor Cells by Altering Phosphatidylinositol 3-Kinase Signaling and Inducing Zac1 Expression
}

\author{
Marily Theodoropoulou, ${ }^{1}$ Jing Zhang, ${ }^{2}$ Sandra Laupheimer, ${ }^{1}$ Marcelo Paez-Pereda, ${ }^{1}$ \\ Christophe Erneux, ${ }^{2}$ Tullio Florio, ${ }^{3}$ Uberto Pagotto, ${ }^{4}$ and Günter K. Stalla ${ }^{1}$ \\ 'Department of Endocrinology, Max Planck Institute of Psychiatry, Munich, Germany; ${ }^{2}$ Institut de Recherche Interdisciplinaire en Biologie \\ Humaine et Moléculaire, Free University of Brussels, Brussels, Belgium; ${ }^{3}$ Department of Oncology, Biology and Genetics, University of \\ Genova, Genova, Italy; and ${ }^{4}$ Endocrine Unit, Department of Internal Medicine and Gastroenterology and Center for Applied \\ Biomedical Research, S. Orsola-Malpighi General Hospital, Bologna, Italy
}

\begin{abstract}
Somatostatin limits cell growth by inhibiting the proliferative activity of growth factor receptors. In this study, it is shown that in pituitary tumor cells, the somatostatin analogue octreotide produces its antiproliferative action by inducing the expression the tumor suppressor gene Zac1. ZAC/Zacl induces cell cycle arrest and apoptosis and is highly expressed in normal pituitary, mammary, and ovarian glands but is down-regulated in pituitary, breast, and ovarian tumors. Knocking down Zac1 by RNA interference abolished the antiproliferative effect of octreotide in pituitary tumor cells, indicating that Zacl is necessary for the action of octreotide. The effect of octreotide on Zac1 expression was pertussis toxin sensitive and was abolished after transfection with a dominant negative vector for SHP-1. Zac1 is a target of the phosphatidylinositol 3-kinase (PI3K) survival pathway. Octreotide treatment decreased the tyrosine phosphorylation levels of the PI3K regulatory subunit p85, induced dephosphorylation of phosphoinositidedependent kinase 1 (PDK1) and Akt, and activated glycogen synthase kinase $3 \beta$ (GSK $\beta$ ). Therefore, in pituitary tumor cells, somatostatin analogues produce their antiproliferative action by acting on the PI3K/Akt signaling pathway and increasing Zac1 gene expression. (Cancer Res 2006; 66(3): 1576-82)
\end{abstract}

\section{Introduction}

Somatostatin regulates neurotransmission, inhibition of hormone secretion, and proliferation, and is used for the treatment of neuroendocrine tumors. Somatostatin binds to a family of receptors (SSTR1-5), which belong to the seven-transmembrane-domain G-protein coupled receptors (GPCR; ref. 1), and exerts its antiproliferative action by inducing $G_{0}-G_{1}$ cell cycle arrest (2) or $\mathrm{G}_{2}-\mathrm{M}$ arrest and apoptosis (3).

Somatostatin binding to SSTR, receptor heterodimerization, G protein sequestration, and the intracellular effectors of SSTR signaling were extensively studied (reviewed in refs. 1, 4-7). Somatostatin limits cell growth by inhibiting the proliferative activity of growth factor receptors. Phosphotyrosine phosphatases (PTP) play a central role in this process by dephosphorylating epidermal growth factor (EGF) receptor (8). Indeed, PTP activity was found to be increased after somatostatin treatment in many cell

Requests for reprints: Marily Theodoropoulou, Department of Endocrinology, Max Planck Institute of Psychiatry, Kraepelinstrasse 10, D-80804 Munich, Germany. Phone: 0049-89-30622292; Fax: 0049-89-30622605; E-mail: marily@mpipsykl.mpg.de.

C2006 American Association for Cancer Research.

doi:10.1158/0008-5472.CAN-05-1189 systems (9-11) and was pertussis toxin sensitive, indicating the involvement of Gi $(8,12)$. SHP-1/PTP1C, which belongs to the cytosolic PTP family and contains Src homology 2 domains, was reported to be recruited to the plasma membrane after somatostatin stimulation $(13,14)$ and to associate with and mediate the antiproliferative effect of SSTR2 (15-17). Another PTP, SHP-2/ PTP1D, was found to mediate the antiproliferative action of SSTR1 in Chinese hamster ovary (CHO)-SSTR1 cells (18) and of SSTR2, SSTR3, and SSTR4 in NIH 3T3 cells stably transfected with each SSTR (19). In CHO cells stably transfected with SSTRs, somatostatin was shown to act through the mitogen-activated protein kinase (MAPK) pathway $(20,21)$. Other studies have also shown that somatostatin can activate the phosphatidylinositol 3-kinase (PI3K) pathway $(20,22)$.

However, there is little information about the transcription factors and gene targets mediating the antiproliferative action of somatostatin. Somatostatin stops cell cycle progression by inducing the cyclin-dependent kinase inhibitor p27/Kip1 $(17,23)$. On the other hand, cells like the rat mammosomatotrophinoma cell line GH3 do not express p27/Kip1 (24) but they nevertheless respond to somatostatin analogue treatment by decreasing cell proliferation, indicating that other genes can mediate the antiproliferative action of somatostatin.

Searching for candidate gene targets, we focused on the putative tumor suppressor gene ZAC/Zacl. In a previous study, ZAC was shown to be highly expressed in the normal anterior pituitary gland but down-regulated in most pituitary adenomas (25). An interesting observation was that acromegaly-associated pituitary adenomas had high ZAC levels, sometimes comparable to the ones found in the normal human anterior pituitaries. Because these tumors derive from patients previously treated with somatostatin analogues, it is possible that their high ZAC expression is due to the somatostatin treatment. The aim of the present study was to investigate whether $\mathrm{ZAC} / \mathrm{Zacl}$ mediates the antiproliferative action of octreotide on GH3 cells and to elucidate the signaling events triggered by octreotide treatment in pituitary tumor cells.

\section{Materials and Methods}

Reagents. Cell culture materials were purchased from Life Technologies (Karlsruhe, Germany), Nunc (Wiesbaden, Germany), and Sigma (St. Louis, MO). Octreotide was provided by the American Peptide Company (Sunnyvale, CA); pertussis toxin, orthovanadate, and PD098059 were from Sigma; and LY294002, wortmannin, SB-415286, and lithium chloride were from Calbiochem (Bad Soden, Germany). Octreotide was dissolved in $0.01 \mathrm{~mol} / \mathrm{L}$ acetic acid and LY294002, wortmannin, and SB-415286 were dissolved in DMSO. 
Cell culture. GH3 cells (American Type Culture Collection, Manassas, VA) were cultured in DMEM supplemented with $10 \%$ FCS, $2.2 \mathrm{~g} / \mathrm{L}$ $\mathrm{NaHCO}_{3}, 10 \mathrm{mmol} / \mathrm{L}$ HEPES, $2 \mathrm{nmol} / \mathrm{L}$ glutamine, $2.5 \mathrm{mg} / \mathrm{L}$ amphotericin $\mathrm{B}$, and 105 units/L penicillin-streptomycin at $37^{\circ} \mathrm{C}$ and $5 \% \mathrm{CO}_{2}$. Cells $\left(4 \times 10^{5}\right)$ were treated with octreotide, pertussis toxin, orthovanadate, LY294002, wortmannin SB-415286, and lithium alone or in the combination appropriate for each experiment, dissolved in serum-free DMEM. The carriers in which the substances were dissolved were used as controls. Pertussis toxin was administered 12 hours, orthovanadate 2 hours, and lithium 1 hour before octreotide treatment. Treatment time was 20 hours unless otherwise indicated.

RNA extraction and semiquantitative reverse transcription-PCR. RNA was extracted by the guanidinium-isothiocyanate-phenol method. PCR for glyceraldehyde-3-phosphate dehydrogenase (GAPDH) was done on $1 \mu \mathrm{g}$ RNA to exclude genomic DNA contamination. One microgram of RNA was reverse transcribed using random hexanucleotides and semiquantitative radioactive PCR was done for Zacl and GAPDH (internal control) under restrictive conditions as previously described (25). Each reverse transcription-PCR (RT-PCR) was done in RNA extracted from three independent experiments.

Western blot analysis. Cells were treated as described for 1, 3, and 6 hours. Cell lysates were separated by PAGE and blotted using standard procedures (26). Primary antibodies were against SHP-1/PTP1C, SHP-2/ PTPID (both made in mouse; Transduction Laboratories, Lexington, KY), Akt, phosphoinositide-dependent kinase 1 (PDK1), glycogen synthase kinase $3 \beta$ (GSK3 $\beta$ ), p70/S6K, FKHR, phosphorylated Akt $\left(\operatorname{Ser}^{473}\right)$, Akt $\left(\mathrm{Thr}^{308}\right)$, PDK1 $\left(\mathrm{Ser}^{241}\right)$, GSK-3 $\beta\left(\mathrm{Ser}^{9}\right)$, phosphatase and tensin homologue (PTEN; $\mathrm{Ser}^{380}$ ), p70/S6K ( $\mathrm{Ser}^{371}$ ), and FKHR ( $\mathrm{Ser}^{256}$; all made in rabbit; New England Biolabs GmbH, Frankfurt am Main, Germany). Horseradish peroxidaseconjugated secondary antibodies were used against mouse and rabbit (Amersham Pharmacia Biotech, Freiburg, Germany). Each Western blot was done in lysates obtained from three independent experiments.

Coimmunoprecipitation. GH3 cells were treated with $1 \mu \mathrm{mol} / \mathrm{L}$ octreotide for 10, 30, and 60 minutes and collected in ice-cold lysis buffer [150 mmol/L NaCl, $50 \mathrm{mmol} / \mathrm{L}$ HEPES (pH 7.4), $1 \mathrm{mmol} / \mathrm{L}$ sodium orthovanadate, $2 \mathrm{mmol} / \mathrm{L} \mathrm{EDTA}, 2 \mathrm{mmol} / \mathrm{L}$ phenylmethylsulfonyl fluoride, and $1 \%$ NP40]. Protein $(600 \mu \mathrm{g})$ was immunoprecipitated with an antibody against the p85 subunit (Upstate, Charlottesville, VA) or with a control mouse immunoglobulin G (IgG). Protein A Sepharose (Amersham Pharmacia Biotech) was used as previously described (26). The immunoprecipitates were extensively washed and protein bound to sepharose was eluted and separated by $10 \%$ SDS-PAGE (27). Western blot was done using the horseradish peroxidase-conjugated anti-phosphotyrosine 4G10 (Upstate), anti-p85, or anti-SHP-1 monoclonal antibody. Coimmunoprecipitation was done in two independent experiments and was repeated using Protein G Sepharose.

Plasmids. SHP-1/C453S (SHP-1dn; ref. 17) and C/S SHP-2 (SHP-2dn; ref. 19) dominant negative mutants and the G $\beta \gamma$ sequester $\beta$-ARK-CT (gift of P. Voigt, Institute of Pharmacology, Charité-Medical University, Campus Benjamin Franklin, Berlin, Germany) were used. The p53-Luc construct (Mercury pathway profiling system, Clontech Laboratories, Inc., Palo Alto, CA) has the p53 responsive element upstream to the TATA box of the herpes simplex virus thymidine kinase promoter and the reporter gene luciferase.

Transfection and reporter assays. Cell transfection was done with SuperFect (Qiagen GmbH, Hilden, Germany). Cells $\left(3 \times 10^{5}\right)$ were transfected for 3 hours with $1 \mu \mathrm{g}$ of SHP-1dn, SHP-2dn, or $\beta$-ARK-CT plasmid, left in cell growth medium overnight, and treated for 20 hours with $1 \mu \mathrm{mol} / \mathrm{L}$ octreotide. RNA was extracted and semiquantitative RTPCR was done for Zacl. Lysates of cells transfected with $\beta$-ARK-CT were analyzed for phosphorylated Akt by Western blot and lysates of cells transfected with SHP-1dn were immunoprecipitated with p85 as described above. Each transfection experiment was done in duplicate. To confirm the SHP-1 and 2dn incorporation, Western blot was done for hemagglutinin (Acris, Hiddenhausen, Germany) and c-myc (Santa Cruz Biotechnology, Santa Cruz, CA), respectively. Incorporation of $\beta$-ARK-CT was shown by determination of $\mathrm{Ca}^{2+}$ oscillations in transfected cells before and after treatment with the muscarinic agonist carbachol (Sigma) as previously described (28).

Cells transfected with p53-Luc were treated with octreotide for 6 hours and luciferase activity was measured by a Berthold luminometer. The pEGFP-C2 vector (Clontech) encoding an optimized variant of the green fluorescent protein (GFP) was used as control of the transfection efficiency. Data are expressed as the ratio of p53 relative luciferase activity to GFP absorbance. Each experiment was done in triplicate.

RNA interference. Double-stranded small interfering RNA (siRNA), with 19-nucleotide (nt) duplex RNA and 2-nt 3' dTdT overhangs, was synthesized by MWG Biotech (Ebersberg, Germany) in deprotected and desalted form using the 2'-ACE technology. The 19-nt pair was 5'-AAGUGCUCCAAGACUGAGUGU, which was designed according to the guidelines described in ref. 29. The sequence was confirmed to be unique for the rat Lot1 using the BLAST search algorithm of the National Center for Biotechnology Information. One scrambled siRNA (Scramble II, MWG Biotech) was used as a control. Similarly, a siRNA was designed against p53 (5'-ACGUGCUCACACUGGCUAATT).

GH3 cells were transfected with $100 \mathrm{nmol} / \mathrm{L}$ "scramble" and with 25 , 50, and $100 \mathrm{nmol} / \mathrm{L}$ siRNA against Zacl using SuperFect (Qiagen) for 3 hours, and then were left in cell growth medium overnight to recover. The day after, they were split and distributed for proliferation or cyclic AMP (cAMP) assays whereas a part was kept for RNA extraction. Cells for RNA extraction were harvested at the same time as the proliferation assay or the cAMP measurement (i.e., 48 hours after transfection with the siRNA). Cells transfected with $100 \mathrm{nmol} / \mathrm{L}$ scramble or siRNA against p53 were treated 1 day after transfection with $1 \mu \mathrm{mol} / \mathrm{L}$ octreotide for 20 hours and RNA was extracted to determine $\mathrm{Zacl}$ gene expression. Each transfection with siRNA was done twice.

Proliferation assays. Cell proliferation was assessed in untreated cells and in cells treated with $1 \mu \mathrm{mol} / \mathrm{L}$ octreotide or $1 \mu \mathrm{mol} / \mathrm{L}$ leptin for 24 hours using the WST-1 assay (Roche Molecular Biochemicals, Mannheim, Germany) as previously described (30).

CAMP RIA. Radioimmunologic cAMP determination was done with a commercial RIA kit from NEN Life Science Products, Inc. (Boston, MA) after $1 \mu \mathrm{mol} / \mathrm{L}$ octreotide treatment. Forskolin $(5 \mathrm{mmol} / \mathrm{L})$ was used as a positive control. The phosphodiesterase inhibitor IBMX ( $5 \mathrm{mmol} / \mathrm{L}$ ) was added to all stimulation solutions. The supernatants were collected and assayed after 4 hours of incubation as previously described (31).

Statistical analysis. Differences were assessed by one-way ANOVA in combination with Scheffés test. $P<0.05$ was considered as significant.

\section{Results}

Octreotide induces the Zacl gene. The somatostatin analogue octreotide increased $\mathrm{Zacl}$ gene expression at concentrations of 1 and $100 \mathrm{nmol} / \mathrm{L}$ (Fig. $1 A$ ) after 6 to 24 hours (Fig. $1 B$ ). This induction pattern is in accordance to the cell cycle kinetics previously described after octreotide treatment in which GH3 cells accumulated in $\mathrm{G}_{0}-\mathrm{G}_{1}$ after 24 hours but there was no effect on cell cycle and number after 48 hours (2).

Knocking down Zac1 by RNA interference abolished the antiproliferative effect of octreotide. To examine the role of Zacl in the antiproliferative signaling of octreotide, we knocked down Zacl using siRNA. siRNA against Zacl increased cell proliferation, similar to what was reported in a previous study using antisense oligonucleotides (Fig. $2 A$; ref. 32). Although 24-hour octreotide treatment decreased cell viability in untransfected GH3 cells and in cells transfected with control siRNA (scramble), it had no effect in cells transfected with 50 and 100 nmol/L siRNA against Zac1 (Fig. 2B). On the other hand, octreotide decreased cAMP in untransfected and transfected cells, indicating that the inability of octreotide to decrease cell proliferation in siRNA-transfected cells is not due to a dysfunctional receptor (Fig. 2C). Furthermore, treatment with leptin, 


\section{A}

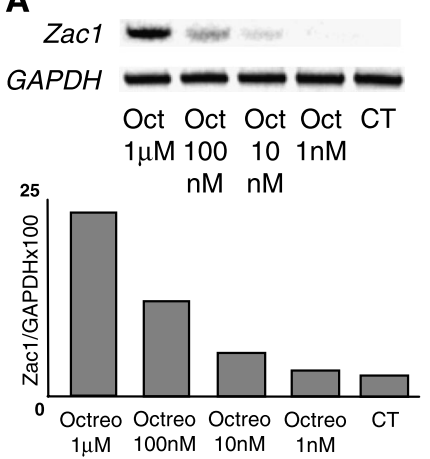

$\mathbf{B}$
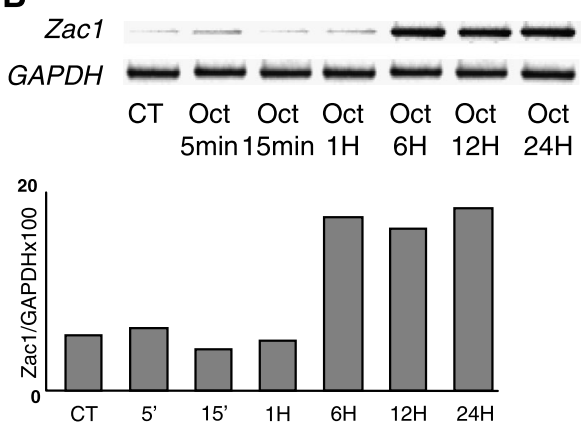

Figure 1. Zac1 expression as determined by RT-PCR after treatment with $1 \mu \mathrm{mol} / \mathrm{L}, 100 \mathrm{nmol} / \mathrm{L}, 10 \mathrm{nmol} / \mathrm{L}$, and $1 \mathrm{nmol} / \mathrm{L}$ octreotide for 24 hours $(A)$ and with $1 \mu \mathrm{mol} / \mathrm{L}$ octreotide for 5 minutes, 15 minutes, $1,6,12$, and 24 hours $(B)$. Each experiment was done thrice.

which does not affect Zacl expression, ${ }^{5}$ decreased cell proliferation in untransfected cells, as well as in scramble- and siRNAtransfected cells, as previously documented (data not shown; ref. 33), further showing that the effect of Zac1 knockdown is specific for octreotide.

The effect of octreotide on Zacl gene expression is pertussis toxin sensitive. Preincubation with $100 \mathrm{ng} / \mathrm{mL}$ pertussis toxin for 12 hours abolished the stimulatory effect of octreotide on Zacl transcription, indicating the involvement of Gi (Fig. $3 A$ ). When activated, Gi generates $\alpha$-subunits and free $\beta \gamma$ dimers. Transfecting GH3 cells with the G $\beta \gamma$ sequester $\beta$-ARK-CT did not influence the effect of octreotide on Zacl expression, indicating the involvement of the $\alpha$-subunit but not of $\beta \gamma$ (Fig. $3 B$ ).

A PTP mediates the stimulatory effect of octreotide on ZacI gene expression. The PTP inhibitor orthovanadate reversed the effect of octreotide on Zac1 (Fig. 3C). Both SHP-1 and SHP-2 were expressed in GH3 cells (data not shown). Cells transfected with dominant negative SHP-1 did not respond to octreotide by increasing Zacl expression whereas transfection with the dominant negative SHP-2 had no effect (Fig. $3 D$ ), indicating that in pituitary cells SHP-1 is required for the action of octreotide.

Octreotide inhibits the PI3K/Akt pathway. We examined which pathways link octreotide to Zac1, downstream of SHP-1. The MAPK inhibitor PD098059 had no effect on basal or octreotide-

\footnotetext{
${ }^{5}$ M. Theodoropoulou, unpublished data.
}

stimulated Zacl levels (data not shown). On the other hand, cells treated with the PI3K inhibitors wortmannin and LY294002 displayed increased Zac1 gene expression (Fig. 4A), indicating that Zac1 is controlled by PI3K and that octreotide may regulate Zacl expression by inhibiting its signaling. Octreotide had no effect on total PDK1 and Akt protein levels but it decreased PDK1 and Akt phosphorylation (Fig. 4B). These effects were pertussis toxin sensitive but were not abolished in cells transfected with $\beta$-ARK$\mathrm{CT}$, indicating involvement of the Gi $\alpha$-subunit but not of the $\beta \gamma$ dimers (data not shown).

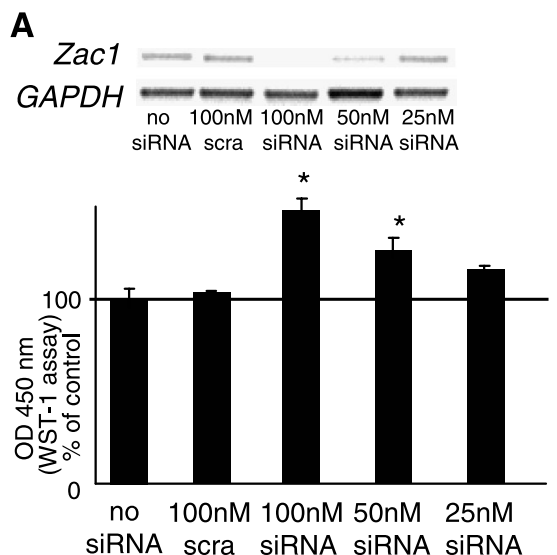

B

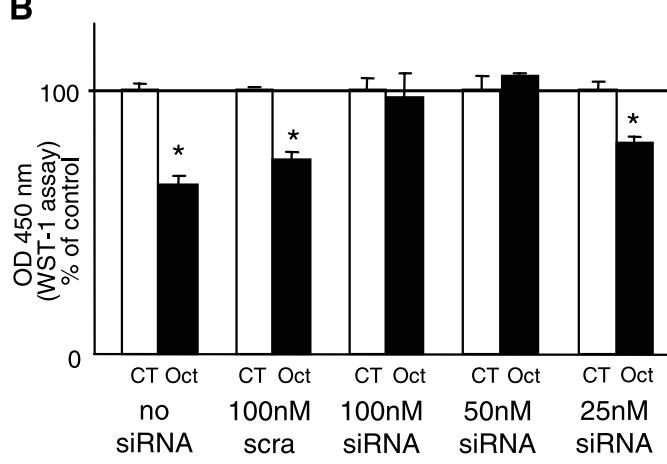

C

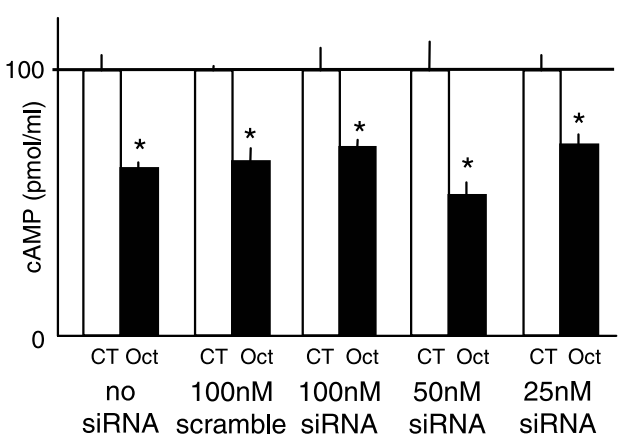

Figure 2. $A$, effect of Zac1 RNA interference on Zac1 mRNA levels in GH3 cell lysates harvested at the same time with the proliferation assay; cell proliferation was determined in untreated cells transfected with scramble, 25, 50, and 100 nmol/L Zac1 siRNA. Percentage of untransfected (no siRNA) cells. * $P<0.05$. $B$, cell proliferation was determined after 24 -hour treatment with $1 \mu \mathrm{mol} / \mathrm{L}$ octreotide. Percentage of each control. ${ }^{*}, P<0.05$. $C$, intracellular cAMP release was determined after 4-hour treatment with $1 \mu \mathrm{mol} / \mathrm{L}$ octreotide. Percentage of each control. * $P<0.05$. Representative of two independent transfection experiments. 


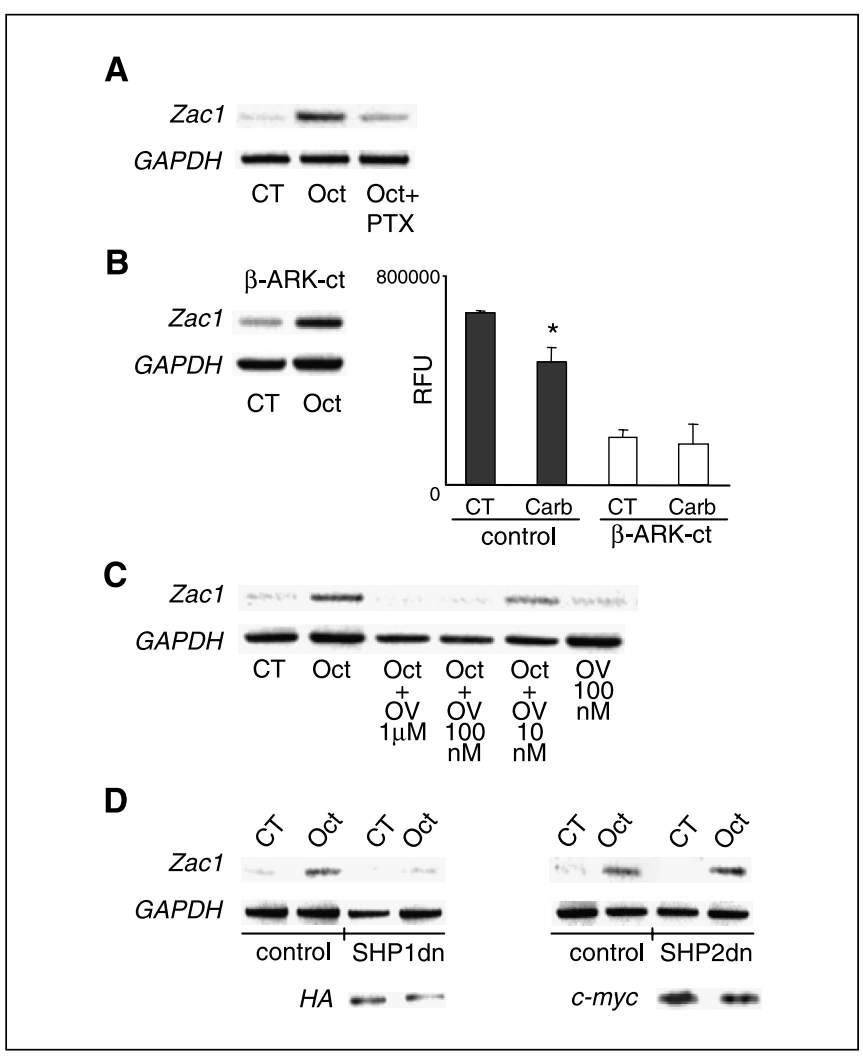

Figure 3. Zac1 expression after 20-hour treatment with $1 \mu \mathrm{mol} / \mathrm{L}$ octreotide, after 16 -hour pretreatment with $100 \mathrm{ng} / \mathrm{mL}$ pertussis toxin $(A)$, and with $1 \mu \mathrm{mol} / \mathrm{L}$ octreotide in cells transfected with the $\beta \gamma$ sequester $\beta$-ARK-CT $(B)$. $\beta$-ARK-CT incorporation is proved by the decrease in $\mathrm{Ca}^{2+}$ oscillation in basal and carbachol-treated $\mathrm{GH} 3$ cells. Each determination was done twice. RFU, relative fluorescence units. ${ }^{*}, P<0.05$. C effect of 2 -hour pretreatment with $1 \mu \mathrm{mol} / \mathrm{L}$, $100 \mathrm{nmol} / \mathrm{L}$, and $10 \mathrm{nmol} / \mathrm{L}$ of the PTP inhibitor orthovanadate on the induced Zac1 expression of octreotide. $D$, effect of $1 \mu \mathrm{mol} / \mathrm{L}$ octreotide on Zac1 gene expression in untransfected $\mathrm{GH} 3$ cells (control) and in cells transfected with a dominant negative vector for SHP-1 (SHP-1dn) or SHP-2 (SHP-2dn). SHP-1dn and SHP-2dn incorporation is shown by Western blot for hemagglutinin $(H A)$ and c-myc, respectively. Similar results were shown by two other experiments. All treatments were done in serum-free DMEM. $A$ and $B$, quantitative analysis of the $A_{\mathrm{ZAC}} / A_{\mathrm{GAPDH}}$ ratio for each sample.

The PI3K pathway is switched off by the lipid phosphatase and tumor suppressor PTEN. However, octreotide did not affect total or phosphorylated PTEN levels (Fig. 4B), suggesting that its inhibitory effect on PDK1/Akt is not due to PTEN activation. PI3K was also shown to be inactivated by SHP-1, which acts by dephosphorylating the PI3K regulatory subunit p85 (27). In GH3 cells, p85 coimmunoprecipitated with SHP-1, confirming the physical association between SHP-1 and p85 (Fig. 4C; ref. 34). Octreotide decreased the levels of p85 detected with the $4 \mathrm{G} 10$ phosphotyrosine antibody (Fig. 4C), but had no effect on p85 phosphorylation in cells transfected with SHP-1dn (Fig. 4D), indicating an important role for SHP-1 in octreotide signaling. Therefore, it is possible that octreotide treatment decreases the phosphorylation levels of the PI3K regulatory subunit p85 and subsequently those of PDK1 and Akt.

Octreotide dephosphorylates and therefore activates GSK3 3 . PDK1 and Akt transduce their signals by phosphorylating and activating or inactivating a number of substrates. Octreotide decreased p70/S6K, FKHR, and GSK3 $\beta$ phosphorylation levels without affecting their total protein levels (Fig. $5 A$ ). Blocking GSK3 $\beta$ with $14 \mu \mathrm{mol} / \mathrm{L}$ SB-415286 or $20 \mathrm{mmol} / \mathrm{L}$ lithium abolished the stimulatory effect of octreotide on Zac1, indicating that Zac1

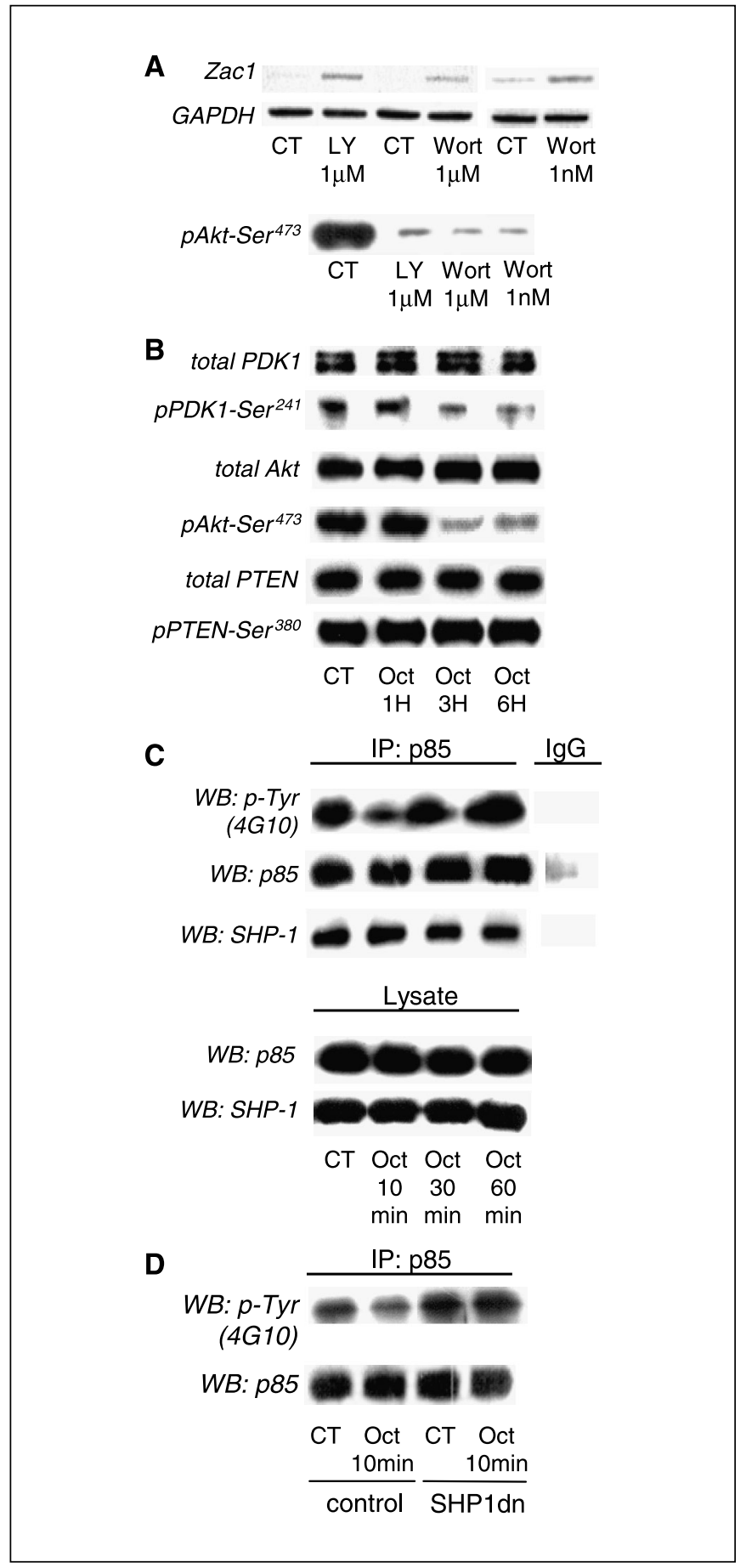

Figure 4. $A$, Zac1 expression after 24-hour treatment with $1 \mu \mathrm{mol} / \mathrm{L}$ $\mathrm{LY}-249002$ and $1 \mu \mathrm{mol} / \mathrm{L}$ and $1 \mathrm{nmol} / \mathrm{L}$ wortmannin, as determined by RT-PCR. Each experiment was done thrice. Western blot for Akt-Ser ${ }^{473}$ shows the efficiency of the inhibitors. $B, \mathrm{GH} 3$ cell lysates treated with $1 \mu \mathrm{mol} / \mathrm{L}$ octreotide for 1,3 , and 6 hours analyzed by Western blot using anti-Akt, anti-pAkt-Ser ${ }^{473}$, anti-PDK1, anti-pPDK1-Ser ${ }^{241}$, anti-PTEN, or anti-pPTEN-Ser ${ }^{380}$. Representative of three experiments. C, GH3 cell lysates were immunoprecipitated with Protein A Sepharose and anti-PI3K-p85 or a control mouse IgG. The immunoprecipitated fractions and the whole-cell lysates were analyzed by Western blot using anti-phosphotyrosine 4G10, anti-p85, and anti-SHP-1. Representative of two experiments. $D$, untransfected and SHP-1dn-transfected GH3 cell lysates, treated for 10 minutes with $1 \mu \mathrm{mol} / \mathrm{L}$ octreotide, were immunoprecipitated with Protein A Sepharose and anti-p85, and the immunoprecipitated fractions were analyzed by Western blot using anti-phosphotyrosine 4G10 and p85. Representative of two experiments. 


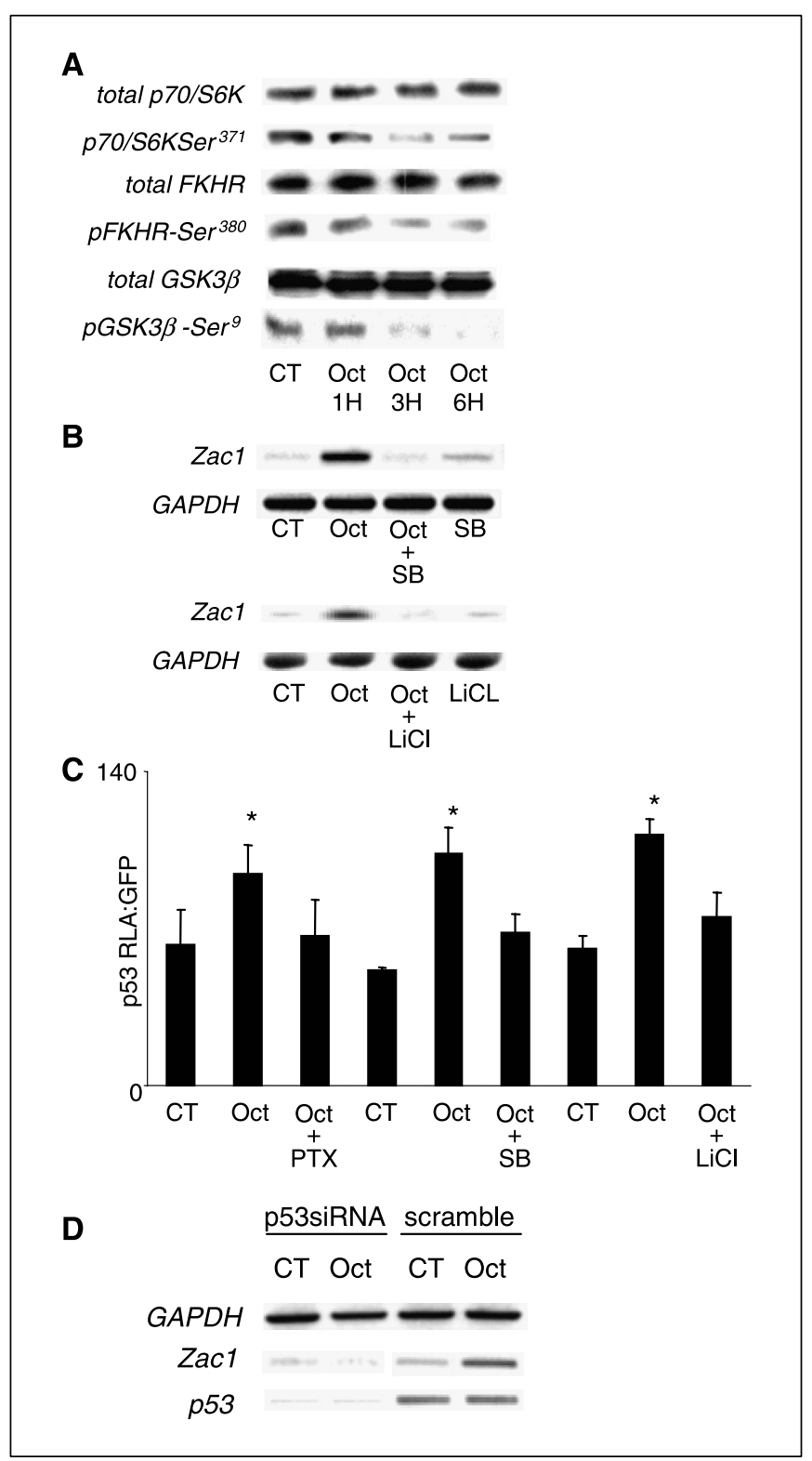

Figure 5. $A, \mathrm{GH} 3$ cell lysates treated with $1 \mu \mathrm{mol} / \mathrm{L}$ octreotide for 1,3 , and 6 hours analyzed by Western blot using anti-p70/S6K, anti-p70/S6K-Ser ${ }^{371}$, anti-FKHR, anti-pFKHR-Ser ${ }^{380}$, anti-GSK3 $\beta$, and anti-pGSK3 $\beta-$ Ser $^{9}$.

Representative of three experiments. $B$, Zac1 expression after 24-hour treatment with $1 \mu \mathrm{mol} / \mathrm{L}$ octreotide alone, octreotide plus $14 \mu \mathrm{mol} / \mathrm{L}$ SB-415286 (SB) or $20 \mathrm{mmol} / \mathrm{L}$ lithium ( $\mathrm{LiCl}$ ), and SB-415286 or lithium alone. Each experiment was done thrice. $C$, effect of 6 -hour treatment with $1 \mu \mathrm{mol} / \mathrm{L}$ octreotide alone after 16 hours of pretreatment with $100 \mathrm{ng} / \mathrm{mL}$ pertussis toxin, $14 \mu \mathrm{mol} / \mathrm{L}$ SB-415286, or $20 \mathrm{mmol} / \mathrm{L}$ lithium on $\mathrm{p} 53$-mediated transcription in $\mathrm{GH} 3$ cells transfected with p53-Luc. $R L A$, relative luciferase activity. Results are shown as p53-RLA/GFP ratio. Each experiment was repeated twice. All treatments were done in serum-free DMEM. D, effect of p53 RNA interference on Zac1 and p53 mRNA levels in untreated $\mathrm{GH} 3$ cells and in cells treated with $1 \mu \mathrm{mol} / \mathrm{L}$ octreotide.

up-regulation happens downstream to GSK3 $\beta$ (Fig. $5 B$ ). Octreotide had no effect on p53 expression, which is one of the GSK3 targets (data not shown), but it increased p53 transcriptional activity, and this effect was pertussis toxin sensitive and was reversed after cotreatment with SB-415286 or lithium (Fig. 5C). Knocking down p53 decreased Zac1 levels and abolished the effect of octreotide on Zac1 transcription (Fig. $5 D$ ). Therefore, octreotide, by blocking GSK3 $\beta$ phosphorylation, activates p53 and increases Zacl gene expression (Fig. 6).

\section{Discussion}

In the present study, it is shown that octreotide increases the expression of the tumor suppressor gene Zacl in a pertussis toxinsensitive mechanism involving the PTP SHP-1. The role of this tumor suppressor gene in the antiproliferative action of octreotide is shown by the fact that cells in which Zacl was knocked down failed to respond to the drug treatment. Therefore, Zacl upregulation is necessary for octreotide to exert its growth inhibiting action. The antiproliferative role of Zacl is indicated by the fact that it induces cell cycle arrest and apoptosis (35) and that loss of Zacl leads to increased pituitary cell growth (32). The role of ZAC as a tumor suppressor is further stressed by the observation that although highly expressed in normal adenohypophysis, it is downregulated in most pituitary adenomas $(25,32)$. Furthermore, Zac1 is lost in transformed rat epithelial ovarian cells (36) and downregulated by the EGF mitogenic signaling (37).

Herein, it is also shown that Zacl is a downstream target of the PI3K survival pathway. PI3K and its downstream targets mediate the growth-promoting and cell survival actions of growth factors, cytokines, and GPCR ligands. On activation, class I PI3Ks phosphorylate phosphatidylinositol-4,5-biphosphates to phosphatidylinositol-3,4,5-triphosphates. Phosphatidylinositol-3,4,5-triphosphate recruits Akt to the plasma membrane and changes its conformation to facilitate its phosphorylation by PDK1 (reviewed in ref. 38). Octreotide treatment in pituitary cells inhibited both PDK1 and Akt phosphorylation.

PI3K activity can be inhibited by the lipid phosphatase and tumor suppressor PTEN. However, we show that octreotide does not affect PTEN, indicating that its inhibitory action on the PI3K pathway is not through PTEN. Still, PI3K activity is under tight regulation by mechanisms controlling its phosphorylation. Class I PI3Ks are

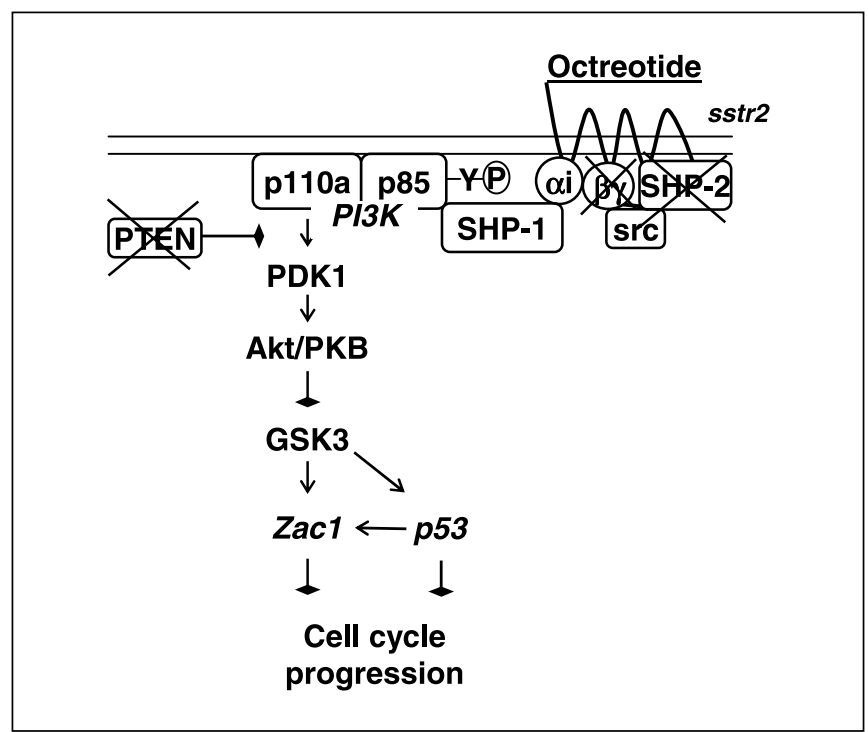

Figure 6. Proposed scheme for the signaling cascade taking place after octreotide treatment in pituitary cells. Because GH3 cells express only SSTR1 and SSTR2 (53) and octreotide can bind to SSTR2, SSTR3, and SSTR5, but not to SSTR1 (1), we assume that this pathway originates from the activated SSTR2. Gia associates with SSTR2 and SHP-1 (15). After 10-minute octreotide treatment, SHP-1 dephosphorylates the PI3K regulatory subunit p85 and probably inactivates PI3K without involving PTEN. Three hours later, PDK1, Akt, and GSK3 $\beta$ are dephosphorylated and GSK3 $\beta$ is activated. This activation results in an increase in p53 transcriptional activity and Zac1 transcription 6 hours after octreotide treatment. In contrast to a previous model (54), G $\beta \gamma$ and SHP-2 were not needed for the action of octreotide in pituitary cells. 
heterodimers consisting of a regulatory subunit (p85 and p101) and a catalytic subunit ( $1110 \alpha, \beta, \gamma$, and $\delta)$. Under resting conditions, p85 stabilizes p110 $\alpha$ and inhibits its kinase activity (39) whereas, on tyrosine phosphorylation, p85 releases its inhibitory action on p110 $\alpha$, leading to PI3K activation. The PTP SHP-1 was described to inhibit PI3K by dephosphorylating p85 (27). In accordance to what was reported before, in pituitary cells, SHP-1 was found to physically associate with p85, implying that because octreotide can activate SHP-1, it may also control PI3K. Indeed, in this study, it is shown that octreotide decreases p85 tyrosine phosphorylation and that SHP-1 plays an important role in this process. Therefore, we speculate that octreotide initiates its antiproliferative signaling by dephosphorylating p85, through SHP-1, and subsequently decreasing the phosphorylation levels of members of the PI3K pathway (Fig. 6).

An interesting observation is the time lapse between the dependent p85 and Akt dephosphorylation of octreotide. Although there is an increasing amount of information about Akt activation, very little is known about the mechanisms governing Akt inactivation (40). There is evidence that Akt resides in lipid rafts where it can remain constitutively active $(41,42)$. Akt trapped in a constitutively active form could explain the time lapse noticed in the present study, but this is a speculation which remains to be examined.

GPCR activates PI3K $\beta$ and PI3K $\gamma$, but not PI3K $\alpha$, through G $\beta \gamma$, and this association is always stimulatory $(43,44)$. Furthermore, Gi coupled receptors activate PI3K $\beta$ also through G $\beta \gamma$ (45). In the case of somatostatin, SSTR1 and SSTR2 were shown to activate PI3K

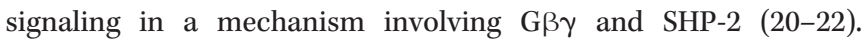
However, in the present study, the effect of octreotide is most probably G $\beta \gamma$ independent because sequestering the $\beta \gamma$ subunits with $\beta$-ARK-CT did not abolish its effect on Akt phosphorylation. These data suggest that Gi-linked GPCR can interact with and inhibit PI3K through the Gi $\alpha$-subunit, revealing a novel way by which GPCR, in general, and SSTRs, in particular, can restrict cell growth.

Akt mediates the antiapoptotic and cell survival effects of growth factors by phosphorylating and subsequently inhibiting FKHR and GSK-3 (46-48). The inhibitory action of octreotide on PDK1 and Akt resulted, as expected, in decreased FKHR and
GSK3 $\beta$ phosphorylation levels. GSK3 $\beta$ inhibition abolished the stimulatory effect of octreotide on $\mathrm{Zacl}$ gene expression, indicating that this tumor suppressor gene is downstream to GSK3 $\beta$. GSK3 $\beta$ regulates cell cycle progression by affecting cyclin $\mathrm{E}$ and cyclin D1 proteolysis and subcellular localization, members of the Forkhead family of transcription factors, the tumor suppressor tuberin (TSC2), and p27/Kip1 (reviewed in refs. 48, 49). Furthermore, GSK3 $\beta$ phosphorylates p53 and activates its transcriptional activity (50). Because p53 activates Zacl transcription (51), it is possible that the effect of octreotide on Zacl is due to up-regulation of p53 transcriptional activity. Indeed, knocking down p53 abolished the stimulatory effect of octreotide on Zacl transcription.

The present study suggests a novel mechanism of octreotide action through direct inhibition of components of the PI3K pathway. This observation contrasts with previous studies in pancreatic tumor cells, in which octreotide did not affect basal, but it inhibited growth factor-induced Akt phosphorylation $(23,52)$, indicating that octreotide signaling can vary among different cell types. Octreotide signaling as described herein initiates by inhibiting the phosphorylation of the PI3K regulatory subunit p85 through the Gi $\alpha$-subunit and SHP-1. Inhibition of the PI3K pathway leads to GSK3 $\beta$ activation, increased p53 transcriptional activity, and subsequently Zac1 up-regulation. Zac1 regulates cell growth and its presence is required for octreotide to stop cell cycle progression, because cells in which Zacl is knocked down cannot respond to the antiproliferative action of this somatostatin analogue.

\section{Acknowledgments}

Received 4/7/2005; revised 10/21/2005; accepted 10/28/2005.

Grant support: Deutsche Forschungs-gemeinschaft grant TH 901/1-2 (M. Theodoropoulou) and a research grant from Novartis Pharma GmbH, Nürnberg Germany (G.K. Stalla).

The costs of publication of this article were defrayed in part by the payment of page charges. This article must therefore be hereby marked advertisement in accordance with 18 U.S.C. Section 1734 solely to indicate this fact.

We thank Dr. Attila Stetak (Department of Medical Chemistry, Semmelweis University, Budapest, Hungary) for his advice and P. Voigt (Institute of Pharmacology, Charité-Medical University, Campus Benjamin Franklin, Berlin, Germany) for the $\beta$-ARK-CT plasmid and discussion. We would also like to thank Dr. C. Bousquet (INSERM U 531, IFR 31, CHU Ranqueil, Toulouse Cedex, France) for her useful comments.

\section{References}

1. Patel YC. Somatostatin and its receptor family. Front Neuroendocrinol 1999;20:157-98.

2. Cheung NW, Boyages SC. Somatostatin-14 and its analog octreotide exert a cytostatic effect on GH3 rat pituitary tumor cell proliferation via a transient $G_{0} / G_{1}$ cell cycle block. Endocrinology 1995;136:4174-81.

3. Srikant CB. Cell cycle dependent induction of apoptosis by somatostatin analog SMS 201-995 in AtT-20 mouse pituitary cells. Biochem Biophys Res Commun 1995;209:400-6.

4. Florio T, Thellung S, Schettini G. Intracellular transducing mechanisms coupled to brain somatostatin receptors. Pharmacol Res 1996;33:297-305.

5. Ferjoux G, Bousquet C, Cordelier P, et al. Signal transduction of somatostatin receptors negatively controlling cell proliferation. J Physiol Paris 2000;94:205-10. 6. Csaba Z, Dournaud P. Cellular biology of somatostatin receptors. Neuropeptides 2001;35:1-23.

7. Bousquet C, Puente E, Buscail L, Vaysse N, Susini C. Antiproliferative effect of somatostatin and analogs. Chemotherapy 2001;47 Suppl 2:30-9.

8. Pan MG, Florio T, Stork PJ. G protein activation of a hormone-stimulated phosphatase in human tumor cells. Science 1992;256:1215-7.
9. Buscail L, Delesque N, Esteve JP, et al. Stimulation of tyrosine phosphatase and inhibition of cell proliferation by somatostatin analogues: mediation by human somatostatin receptor subtypes SSTR1 and SSTR2. Proc Natl Acad Sci U S A 1994;91:2315-9.

10. Florio T, Rim C, Hershberger RE, Loda M, Stork PJ. The somatostatin receptor SSTR1 is coupled to phosphotyrosine phosphatase activity in CHO-K1 cells. Mol Endocrinol 1994;8:1289-97.

11. Reardon DB, Wood SL, Brautigan DL, Bell GI, Dent P, Sturgill TW. Activation of a protein tyrosine phosphatase and inactivation of Raf- 1 by somatostatin. Biochem J 1996;314:401-4.

12. Dent P, Reardon DB, Wood SL, et al. Inactivation of raf-1 by a protein-tyrosine phosphatase stimulated by GTP and reconstituted by Gai/o subunits. J Biol Chem 1996;271:3119-23.

13. Zeggari M, Esteve JP, Rauly I, et al. Co-purification of a protein tyrosine phosphatase with activated somatostatin receptors from rat pancreatic acinar membranes. Biochem J 1994;303:441-8.

14. Srikant CB, Shen SH. Octapeptide somatostatin analog SMS 201-995 induces translocation of intracellular PTP1C to membranes in MCF-7 human breast adenocarcinoma cells. Endocrinology 1996;137: 3461-8.
15. Lopez F, Esteve JP, Buscail L, et al. The tyrosine phosphatase SHP-1 associates with the sst2 somatostatin receptor and is an essential component of sst2 mediated inhibitory growth signaling. J Biol Chem 1997, 272:24448-54.

16. Bousquet C, Delesque N, Lopez F, et al. sst2 somatostatin receptor mediates negative regulation of insulin receptor signaling through the tyrosine phosphatase SHP-1. J Biol Chem 1998;273:7099-106.

17. Pages P, Benali N, Saint-Laurent N, et al. sst2 somatostatin receptor mediates cell cycle arrest and induction of p27(Kipl). Evidence for the role of SHP-1. J Biol Chem 1999;274:15186-93.

18. Florio $T$, Thellung $S$, Arena $S$, et al. Somatostatin receptor 1 (SSTR1)-mediated inhibition of cell proliferation correlates with the activation of the MAP kinase cascade: role of the phosphotyrosine phosphatase SHP-2. J Physiol Paris 2000;94:239-50.

19. Reardon DB, Dent P, Wood SL, Kong T, Sturgill TW. Activation in vitro of somatostatin receptor subtypes 2, 3 , or 4 stimulates protein tyrosine phosphatase activity in membranes from transfected Ras-transformed NIH 3T3 cells: coexpression with catalytically inactive SHP-2 blocks responsiveness. Mol Endocrinol 1997;11:1062-9. 20. Florio T, Yao H, Carey KD, Dillon TJ, Stork PJ. Somatostatin activation of mitogen-activated protein 
kinase via somatostatin receptor 1 (SSTR1). Mol Endocrinol 1999;13:24-37.

21. Lahlou H, Saint-Laurent N, Esteve JP, et al. sst2 Somatostatin receptor inhibits cell proliferation through Ras-, Rapl-, and B-Raf-dependent ERK2 activation. J Biol Chem 2003;278:39356-71.

22. Stetak A, Csermely P, Ullrich A, Keri G. Physical and functional interactions between protein tyrosine phosphatase $\alpha$, PI 3-kinase, and PKC $\delta$. Biochem Biophys Res Commun 2001;288:564-72.

23. Medina DL, Velasco JA, Santisteban P. Somatostatin is expressed in FRTL-5 thyroid cells and prevents thyrotropin-mediated down-regulation of the cyclindependent kinase inhibitor p27kipl. Endocrinology 1999;140:87-95.

24. Qian X, Jin L, Grande JP, Lloyd RV. Transforming growth factor- $\beta$ and p27 expression in pituitary cells. Endocrinology 1996;137:3051-60.

25. Pagotto U, Arzberger T, Theodoropoulou M, et al. The expression of the antiproliferative gene $\mathrm{ZAC}$ is lost or highly reduced in nonfunctioning pituitary adenomas. Cancer Res 2000;60:6794-9.

26. Paez-Pereda M, Giacomini D, Refojo D, et al Involvement of bone morphogenetic protein 4 (BMP-4) in pituitary prolactinoma pathogenesis through a Smad/ estrogen receptor crosstalk. Proc Natl Acad Sci U S A 2003;100:1034-9.

27. Cuevas BD, Lu Y, Mao M, et al. Tyrosine phosphorylation of p85 relieves its inhibitory activity on phosphatidylinositol 3-kinase. J Biol Chem 2001;276 27455-61.

28. Kleuss C, Scherubl H, Hescheler J, Schultz G, Wittig B. Selectivity in signal transduction determined by $\gamma$ subunits of heterotrimeric G proteins. Science 1993, 259:832-4.

29. Elbashir SM, Harborth J, Lendeckel W, Yalcin A Weber K, Tuschl T. Duplexes of 21-nucleotide RNAs mediate RNA interference in cultured mammalian cells. Nature 2001;411:494-8.

30. Paez PM, Missale C, Grubler Y, Arzt E, Schaaf L, Stalla GK. Nerve growth factor and retinoic acid inhibit proliferation and invasion in thyroid tumor cells. Mol Cell Endocrinol 2000;167:99-106.

31. Stalla GK, Stalla J, von Werder K, et al. Nitroimidazole derivatives inhibit anterior pituitary cell function apparently by a direct effect on the catalytic subunit of the adenylate cyclase holoenzyme. Endocrinology 1989;125:699-706.

32. Pagotto U, Arzberger T, Ciani E, et al. Inhibition of Zacl, a new gene differentially expressed in the anterior pituitary, increases cell proliferation. Endocrinology 1999;140:987-96

33. Jin L, Burguera BG, Couce ME, et al. Leptin and leptin receptor expression in normal and neoplastic human pituitary: evidence of a regulatory role for leptin on pituitary cell proliferation. J Clin Endocrinol Metab 1999;84:2903-11.

34. Cuevas B, Lu Y, Watt S, et al. SHP-1 regulates Lckinduced phosphatidylinositol 3-kinase phosphorylation and activity. J Biol Chem 1999;274:27583-9.

35. Spengler D, Villalba M, Hoffmann A, et al. Regulation of apoptosis and cell cycle arrest by Zacl, a novel zin finger protein expressed in the pituitary gland and the brain. ЕMBO J 1997;16:2814-25.

36. Abdollahi A, Godwin AK, Miller PD, et al. Identification of a gene containing zinc-finger motif based on lost expression in malignantly transformed rat ovarian surface epithelial cells. Cancer Res 1997;57: 2029-34.

37. Abdollahi A, Bao R, Hamilton TC. LOT1 is a growth suppressor gene down-regulated by the epiderma growth factor receptor ligands and encodes a nuclea zinc-finger protein. Oncogene 1999;18:6477-87.

38. Vanhaesebroeck B, Alessi DR. The PI3K-PDK connection: more than just a road to PKB. Biochem J 2000;346 Pt 3:561-76.

39. Yu J, Zhang Y, Mcllroy J, Rordorf-Nikolic T, Orr GA, Backer JM. Regulation of the p85/p110 phosphatidylinositol 3'-kinase: stabilization and inhibition of the p110 $\alpha$ catalytic subunit by the p85 regulatory subunit. Mol Cell Biol 1998;18:1379-87.

40. Leslie NR, Biondi RM, Alessi DR. Phosphoinositideregulated kinases and phosphoinositide phosphatases. Chem Rev 2001;101:2365-80.

41. Elhyany S, Assa-Kunik E, Tsory S, et al. The integrity of cholesterol-enriched microdomains is essential fo the constitutive high activity of protein kinase B in tumour cells. Biochem Soc Trans 2004;32:837-9.

42. Hill MM, Feng J, Hemmings BA. Identification of a plasma membrane Raft-associated PKB Ser473 kinase activity that is distinct from ILK and PDK1. Curr Biol 2002;12:1251-5.
43. Stoyanov B, Volinia S, Hanck T, et al. Cloning and characterization of a $\mathrm{G}$ protein-activated human phosphoinositide-3 kinase. Science 1995;269:690-3. 44. Hawes BE, Luttrell LM, van Biesen T, Lefkowitz RJ. Phosphatidylinositol 3-kinase is an early intermediate in the $G \beta \gamma$-mediated mitogen-activated protein kinase signaling pathway. J Biol Chem 1996;271:12133-6.

45. Yart $A$, Roche $S$, Wetzker $R$, et al. A function for phosphoinositide 3-kinase $\beta$ lipid products in coupling $\beta \gamma$ to Ras activation in response to lysophosphatidic acid. J Biol Chem 2002;277:21167-78.

46. Cross DA, Alessi DR, Cohen P, Andjelkovich M, Hemmings BA. Inhibition of glycogen synthase kinase-3 by insulin mediated by protein kinase B. Nature 1995; 378:785-9.

47. Kennedy SG, Wagner AJ, Conzen SD, et al. The PI 3-kinase/Akt signaling pathway delivers an antiapoptotic signal. Genes Dev 1997;11:701-13.

48. Kim L, Kimmel AR. GSK3, a master switch regulating cell-fate specification and tumorigenesis. Curr Opin Genet Dev 2000;10:508-14.

49. Liang J, Slingerland JM. Multiple roles of the PI3K/ PKB (Akt) pathway in cell cycle progression. Cell Cycle 2003;2:339-45.

50. Turenne GA, Price BD. Glycogen synthase kinase $3 \beta$ phosphorylates serine 33 of p53 and activates p53's transcriptional activity. BMC Cell Biol 2001;2:12.

51. Rozenfeld-Granot G, Krishnamurthy J, Kannan K, et al. A positive feedback mechanism in the transcriptional activation of Apaf-1 by p53 and the coactivator Zac-1. Oncogene 2002;21:1469-76.

52. Charland S, Boucher MJ, Houde M, Rivard N Somatostatin inhibits Akt phosphorylation and cell cycle entry, but not p42/p44 mitogen-activated protein (MAP) kinase activation in normal and tumoral pancreatic acinar cells. Endocrinology 2001;142:121-8. 53. Garcia PD, Myers RM. Pituitary cell line GH3 expresses two somatostatin receptor subtypes that inhibit adenylyl cyclase: functional expression of rat somatostatin receptor subtypes 1 and 2 in human embryonic kidney 293 cells. Mol Pharmacol 1994;45: 402-9.

54. Ferjoux G, Lopez F, Esteve JP, et al. Critical role of Src and SHP-2 in sst2 somatostatin receptor-mediated activation of SHP-1 and inhibition of cell proliferation. Mol Biol Cell 2003;14:3911-28. 